EARTHLY DELIGHTS 


\section{Princeton Series of Contemporary Poets}

Susan Stewart, series editor

For other titles in the Princeton Series of Contemporary Poets see the end of this volume. 


\title{
EARTHLY DELIGHTS
}

\author{
Poems
}

Troy Jollimore

PRINCETON UNIVERSITY PRESS

Princeton and Oxford 
Copyright (C) 2021 by Princeton University Press

Princeton University Press is committed to the protection of copyright and the intellectual property our authors entrust to us. Copyright promotes the progress and integrity of knowledge. Thank you for supporting free speech and the global exchange of ideas by purchasing an authorized edition of this book. If you wish to reproduce or distribute any part of it in any form, please obtain permission.

Requests for permission to reproduce material from this work should be sent to permissions@press.princeton.edu

Published by Princeton University Press

41 William Street, Princeton, New Jersey 08540

6 Oxford Street, Woodstock, Oxfordshire OX20 1TR

press.princeton.edu

All Rights Reserved

Library of Congress Cataloging-in-Publication Data

Names: Jollimore, Troy A., 1971- author.

Title: Earthly delights : poems / Troy Jollimore.

Description: First edition. | Princeton : Princeton University Press,

[2021] | Series: Princeton series of contemporary poets

Identifiers: LCCN 2021003001 | ISBN 9780691218830 (hardcover) |

ISBN 9780691218823 (paperback) | ISBN 9780691218847 (ebook)

Subjects: LCGFT: Poetry.

Classification: LCC PR9199.4.J658 E23 2021 | DDC 811/.6—dc23

LC record available at https://lccn.loc.gov/2021003001

British Library Cataloging-in-Publication Data is available

Editorial: Anne Savarese and James Collier

Production Editorial: Ellen Foos

Text Design: Pamela Schnitter

Jacket/Cover Design: Pamela Schnitter

Production: Erin Suydam

Publicity: Jodi Price and Amy Stewart

Copyeditor: Daniel Simon

Cover art: Joris Hoefnagel (1542-1600), A Sloth, 1561-1562.

This book has been composed in Adobe Garamond and Scala Sans

Printed on acid-free paper. $\infty$

Printed in the United States of America

109876554321

Excerpt from "American Beauty" from The Invisible Dragon: Essays on Beauty, Revised and Expanded by Dave Hickey. Copyright (C) 2009 by the University of Chicago. Text copyright @ 2009,1993 by Dave Hickey.

Reprinted by permission of the University of Chicago Press. 